\title{
Corporate Criminal Intent: Toward a Better Understanding of Corporate Misconduct
}

\author{
Ann Foerschler $\dagger$
}

\begin{abstract}
Although corporations can be "persons" in certain legal contexts, they cannot so easily be criminals. Recognition of criminal liability for corporate entities has been slow in coming in the law. The prosecution of corporations for intent crimes has been particularly problematic. For such crimes, the law has attempted to anchor the criminal liability of corporations to the intent of individuals within the corporation. Organizational theory, through its several models of corporate decisionmaking, confirms that borrowing intent from individual corporate actors may not be productive, since some corporate acts can never be traced to the intent of any one individual. This Comment suggests a framework to replace the conventional rule of imputing criminal intent directly from individuals to the corporation. The author adopts a framework with a nonreductionist approach, looking solely to corporate practices and policies for the inquiry. The author creates a three-part test to determine corporate intent, asking whether a corporate practice or policy violated the law, whether it was reasonably foreseeable that such a policy would lead a corporate agent to violate the law, or whether the corporation adopted that agent's violation of the law. The author argues that this framework more accurately identifies culpability for criminal acts within complex corporate structures.
\end{abstract}

\section{INTRODUCTION}

The issue of corporate criminal liability raises a number of difficult questions. Ample scliolarly discourse has addressed several of these questions. For exanple, numerous comments and articles have discussed the justifications for imposing criminal liability on corporations. ${ }^{1}$ Similarly, various legal scliolars have analyzed the imposition of sanctions on

$\dagger$ B.A. 1988, Trinity University; J.D. candidate 1991, Boalt Hall School of Law, University of California, Berkeley. I would like to thank Professor Angela Harris, Professor Bryan Ford, Professor Jan Vetter, Richard Flisher, Maria Crisera, Audra Eckerle, and the members of the Califortia Law Review for their helpful comments and assistance in preparing this Comment. I would especially like to thank Dr. John Lindquist of Trinity University who provided the inipetus for this Comment.

1. See, e.g., Edgerton, Corporate Criminal Responsibility, 36 YALE L.J. 827 (1927) (arguing that a corporation should be liable for any crinie coninitted by its employees in the course of their employment and urging the same justifications for corporate liability as are found in cases of individual liability); Ledernan, Criminal Law, Perpetrator and Corporation: Rethinking a Complex 
corporations. ${ }^{2}$ This Comment will focus on another question raised by the existence of corporate criminal liability: low can crimmal intent be imputed to a corporation $?^{3}$ The Cominent first argues that the common law rule that mtent must be imputed from individuals to the corporation is based on overly simplistic notions of corporate structure. Drawing on organizational theory, it then suggests a framework within whicl the corporation itself may be considered capable of "intent."

Triangle, 76 J. CRIM. L. \& CRIMINology 285, $295-324$ (1985) (criticizing traditional justifications for imposing corporate criminal liability); Note, Can a Corporation Commit Murder?, 64 WASH. U.L.Q. 967, 968, 976-84 (1986) (authored by Alana L. Helverson) (arguing that states are justified, for public policy reasons, in holding corporations criminally liable for homicide offenses).

2. See, e.g., Coffee, "No Soul to Damn: No Body to Kick": An Unscandalized Inguiry Into the Problem of Corporate Punishment, 79 MICH. L. REV. 386, 388-434 (1981) (discussing the inadequacies of the current method of imposing corporate sanctions and proposing an alternative sanction); Lederman, supra note 1, at 309-24 (arguing that the current sanctions are inefficient and ineffective); Silets \& Bremer, The Demise of Rehabilitation: Sentencing Reform and the Sanctioning of Organizational Criminality, 13 AM. J. CRIM. L. 329 (1986) (analyzing current sanctions for corporate criminality and sentencing strategies).

3. One might argue that this so-called "institutional intent" is not really a form of mens rca, because mens rea involves moral responsibility for an act, and only people - not abstract organizations-can be moral agents. For essays discussing botli sides of this issue, see SHAME, RESPONSIBILITY AND THE CoRPoRATION (H. Curtler ed. 1986). Professor Frencli has written extensively within the philosophical field on the moral nature of the corporation, and he argues that corporations do lave "moral personlıod," which requires only the eapabilities for intentional action and for reform. P. French, Collective and Corporate Responsibility 165 (1984). Because neitler infants nor the severely retarded have these requisite capabilities, they cannot form criminal intent. See Thounpson, Why Do We Need a Theory of Corporate Responsibility?, in SHAME, RESPONSIBILITY AND THE CoRporation, supra, at 113, 127. Corporations do fulfill these two criteria, however, and tlus can properly be considered as having the inoral personhood required for criminal liability. P. FRENCH, supra, at 164-72. But cf. Lederman, supra note 1, at 307 (arguing that the concept of a corporate mind is a total fiction).

This Cominent does not enter that debate. Mens rea is not an objective reality which a person does or does not possess, but is rather a label which the legal system attaches in order to make a particular social conclusion-that an actor should be held criminally responsible. As H.L.A. Hart argues, legal terms such as mens rea have meaning only "as part of a sentence the function of which as a whole is to draw a conclusion of law from a specific kind of legal rule." Hart, Definition and Theory in Jurisprudence, 70 LAw Q. REv. 37, 43 (1954).

The relevant question is whetler we want to categorize "corporate intent" as another form of mens rea. I will argue that we do, although $I$ concede that this new form of mens rea is different from what we liave heretofore categorized under that label. It is not the product of an "evil mind," but rather the product of a system. But only analogy, not identity, is necessary to classify phenomena under the same legal term. See id. at 59.

Thus, the fact that the meaning of mens rea shifts somewhat when we speak of corporate intent has no effect on its logical consistency. We have simply expanded the concept of mens rea to include corporate intent as well as individual intent. The fact that society has expressed its wish to hold corporations hable not only justifies but necessitates such expansion. See Hart, The Aims of the Criminal Law, 23 LAw \& CONTEMP. ProBs. 401, 404 (1958) (discussing the method of the criminal law); Swigert \& Farrell, Corporate Homicide: Definitional Processes in the Creation of Deviance, 15 LAW \& Soc'Y REV. 161, 178.80 (1981) (tracing the changing definition of corporate criminal liability). 


\section{A. Rationale for Prosecuting Corporations}

Why attempt to prosecute a corporation at all? Is it not sufficient to prosecute the imdividuals involved? A negative answer to this question stems from the assumption that the corporate system itself sometimes helps produce criminal behavior.

This assumption has an empirical basis. A policy of solely prosecuting individuals provides an mcentive for the corporate management to view particular individuals as "expendable." Corporate policies may encourage illegal behavior, often imphicitly, ${ }^{5}$ then simply allow the imdividuals who are caught to be jettisoned. ${ }^{6}$ In large corporations, for example, individual managers may be considered a "fungible commodity." In fact, researchers have documented that some corporations have officers who are in essence appointed fall guys-"vice-presidents responsible for going to jail." 8

A strategy of himiting prosecution to individuals ignores any pressures imposed by the organizational structure. ${ }^{9}$ Although an imdividual has been prosecuted, the incentive system which led to the crimmal behavior remains imtact within the corporation. Not only does prosecution of individuals im such situations fail to deter the corporation, but also indemnification of employees by the corporation may negate the deterrent effect on the individuals. ${ }^{10}$ The latter problem is real since many indemnification statutes allow for indemnification in crimmal as well as civil actions. ${ }^{11}$

Assuming that in a number of cases the organizational incentive structure causes, or at least contributes, to the individual misconduct, the law should attach blame to the corporation as well as to the individual. In these situations, the deterrent value of the stigma that results from criminal conviction is as useful against the corporation as it is against the

4. Silets \& Brenner, supra note 2, at 354.

5. Martin and Carolyn Needleman discuss the theory that organizations can have a "crimecoercive" corporate structure, in which criminal activity that benefits the organization is desired by policymakers and thus conditions are set up to lead lower-level members to break the law. Needleman \& Needleman, Organizational Crime: Two Models of Criminogenesis, 20 Soc. Q. 517, 518-21 (1979). They also argue that there is an additional useful model in which corporations can facilitate, while not coerce, crime by providing incentives in a low-risk environment. $I d$.

6. Coffee, supra note 2, at 409-10.

7. Id. at 410 .

8. J. Braithwaite, Corporate Crime in the Pharmaceutical Industry 308 (1984).

9. Schrager \& Short, Toward a Sociology of Organizational Crime, 25 Soc. PROBS. 407, 410 (1978).

10. Brickey, Rethinking Corporate Liability Under the Model Penal Code, 19 RUTGERS L.J. $593,621-23$ (1988). Of course, indemnification does not have this effect if the individuals are given significant jail terms.

11. See, e.g., Del. Code ANin. tit. 8, § 145 (1974). 
individual. ${ }^{12}$ But if only the individual is prosecuted, even with the negative pubhicity, the corporate entity avoids anything more than circumstantial identification with the crime. In addition to the deterrent purpose, identifying the organizational system as responsible also serves to identify the need for reform at the corporate level. ${ }^{13}$

\section{B. The Problem of Inconsistent Verdicts}

Prosecuting both the corporation and the individuals involved in criminal conduct has proved problematic. In a number of cases in which both were jointly tried for an offense, the jury convicted the corporate defendant and acquitted the individual defendants. Since both conduct and intent inust be imputed from the mdividual to the corporation, the result in these cases has left judges and scholars scratching their heads. Legal scholars have posited that the inconsistent verdicts may reflect more than "capricious judgment" on the part of the juries. ${ }^{14}$ Sorne scholars beheve that these verdicts inay represent a certain hesitancy to subject the individual corporate agents to the harmful "social consequences" of a criminal conviction. ${ }^{15}$ Alternatively, inconsistent verdicts may be the result not of naiveté, but of jury insight into the existence of organizational pressures that may have contributed to the violation. ${ }^{16}$

Appellate courts have responded in several ways to such inconsistent verdicts. A few have found the inconsistency fatal to the verdict against the corporation. In Pevely Dairy Co. v. United States, which involved antitrust violations, the court stated that the conviction of the corporate defendants and the acquittal of the individual defendants "stripped the verdict . . of all semblance of logic."17 In Imperial Meat

12. Braithwaite \& Geis, On Theory and Action for Corporate Crime Control, 28 Crime \& DelinQ. 292, 301-05 (1982); Brickey, Remarks from the Model Penal Code Conference TranscriptDiscussion Two (Nov. 6, 1987), reported in 19 RUTGERS L.J. 635, 635 (1988).

13. Thompson, supra note 3 , at 119.

14. See Model Penal CoDE $\S 2.07$ comment 2 (1962).

15. Id. This supposed hesitancy is consistent with the view that the public is more lenient toward white-collar and organizational crime. See Comment, Criminal Sanctions for Corporate Illegality, 69 J. CRIM. L. \& CRiminology 40, 42 (1978) (authored by Stephen A. Yoder). This assumption about the public lias been called into question by recent studies. See, e.g., Brickey, supra note 12, at 635 (reporting Professor Kathleen Brickey's statement that "[i]n some surveys, organizational crimes were rated as serious as individual crimes when they had common impacts"); Hans \& Elırmann, Responses to Corporate Versus Individual Wrongdoing, 13 LAW \& HuM. BEHAV. 151,163 (1989) (describing researcl indicating that public leniency toward corporations is a mytl and that the public lias strong attitudes of condemnation toward corporate misbehavior; in some cases public holds corporations more accountable than it does individuals for identical conduct);

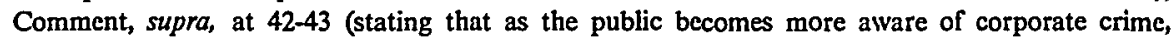
resentment will grow and people will favor stronger criminal sanctions).

16. Model Penal Code $\S 2.07$ comment 2 .

17. 178 F.2d 363, 370-71 (8th Cir. 1949), cert. denied, 339 U.S. 942 (1950) (reversing the corporate conviction on the grounds of insufficient evidence and citing the inconsistency of the verdicts as support for the reversal). 
Co. v. United States, ${ }^{18}$ also a case involving antitrust violations, the appellate court upheld an instruction that the jury inust find at least one of the individual defendants guilty in order to find the corporation guilty. ${ }^{19}$

In American Medical Association v. United States, ${ }^{20}$ however, the D.C. Circuit upheld the "inconsistent" convictions of the two corporate defendants without acknowledging any inconsistency in the verdicts. ${ }^{21}$ The associations and key individuals were charged with antitrust violations, and although the individuals were acquitted, the court stated: "When a corporation is guilty of crime it is because of a corporate act, a corporate intent .... The fact that a corporation can act only by human agents is immaterial."22

The above cases illustrate that, by and large, courts have regarded these inconsistent verdicts as being at least partly irrational. The significance of these cases hes in their suggestion of soinething inore than jury irrationality. They indicate that these juries inay have recoginzed a fact that the legal system has not: namely, that corporations are not always reducible to individuals.

This Comment argues that the traditional notion that intent inust be imputed from individuals to the corporation is based on overly simplistic notions of corporate structure. Drawing on organizational theory, it suggests a framework within which the corporation in and of itself may be considered capable of "intent." Such a framework achieves the benefits of holding corporations criminally hable while avoiding the problem of inconsistent verdicts.

Section I(A) provides a brief history of the development of corporate criminal hability, focusing primarily on the development of liability for intent crimes. Section $I(B)$ explores the current method of prosecuting corporations and of imputing intent to them. Section I(B) also discusses the limitations of the current rule of imputing intent and suggests that the rule should be reconsidered. Part II addresses current models of corporate decisionmaking based on organzational theory. Finally, Part III presents a framework upon which a concept of corporate intent can be based and suggests that this framework should replace the current rule. The Comment concludes that a concept of corporate intent can and should be incorporated into the criminal law.

18. 316 F.2d 435 (10th Cir.), cert. denied, 375 U.S. 820 (1963).

19. Id. at 440 .

20. 130 F.2d 233 (D.C. Cir. 1942), aff'd, 317 U.S. 519 (1943).

21. Id. at 253 .

22. Id. 
I

\section{The Problem of Finding Corporate "Intent"}

\section{A. The Development of Corporate Criminal Liability ${ }^{23}$}

\section{Common Law Developments}

English law established the corporation in the fourteenth century, ${ }^{24}$ but it did not consider a corporation capable of criminal acts until three centuries later. ${ }^{25}$ The first corporate crime cases were prosecutions of public corporations (such as towns and counties) for failing to abate pubhic nuisances. ${ }^{26}$ Courts decided that liability should run to the collective entity ratlier than to mdividual officeholders. ${ }^{27}$ With the advent of the railroads, prosecution of private business corporations for similar public nuisance offenses began. ${ }^{28}$

Courts reasoned that since a corporation was not a pliysical being, it could not commit positive acts-but it could fail to act. ${ }^{29}$ This view initially predominated in America as well as in England, but in the middle of the nineteentli century both countries dismissed the misfeasance/nonfeasance distinction as arbitrary, and began to allow the prosecution of corporations for acts as well as omissions. ${ }^{30}$

Courts agreed, however, that while corporations could be criminally prosecuted, they could not be prosecuted for offenses requiring intent. ${ }^{31}$ This distimction rested on the characterization of intentional offenses as deriving from the "corrupted mind." 32 Since corporations had no mind, they could not be guilty of crimes requiring criminal intent.

This distinction proved short-lived as well, because in 1909 the Umited States Supreme Court upheld a law that attributed crininal intent to a corporation. ${ }^{33}$ In New York Central and Hudson River Railroad Co.

23. This will be a brief exposition of the historical development. For a more detailed discussion, see K. Brickey, Corporate Criminal liability: A Treatise on the Criminal. Liability of CoRporations, Their OfFICERS AND Agents $\$ \S 1-4$ (1984); Bernard, The Historical Development of Corporate Criminal Liability, 22 CRIMINOLOGY 3 (1984); Silets \& Brenner, supra note 2, at 332-49; Stoner, Corporate Criminal Liability for Homicide: Can the Criminal Law Control Corporate Behavior?, 38 Sw. L.J. 1275, 1276-85 (1985); Comment, Corporate Criminal Liability for Homicide: Has the Fiction Been Extended Too Far?, 4 J.L. \& CoMM. 95, 96105 (1984) (authored by Patricia B. Rodella); Note, supra note 1, at 968-72.

24. Silets \& Brenner, supra note 2 , at 332.

25. Elkins, Corporations and the Criminal Law: An Uneasy Alliance, 65 KY. L.J. 73, 86-87 (1976) (tracing the historical development of imputing intent to corporations).

26. Id. at 87.

27. Id.

28. Bernard, supra note 23 , at 7 .

29. Silets \& Brenner, supra note 2 , at 339.

30. Bernard, supra note 23 , at 8 .

31. Id.

32. Id. (quoting Queen v. Great N. of England Ry., 115 Eng. Rep. 1294, 1298 (1846)).

33. Id. at 9. In 1917, English courts followed suit in Mousell Bros., Ltd. v. London \& NorthWestern Railway, 2 K.B. 836 (1917). 
v. United States, ${ }^{34}$ the Court held constitutionally valid a provision of the Elkins Act that construed acts of the corporate officers as both individual acts and as acts of the corporation, thus imputing intent froin the individual to the corporation. ${ }^{35}$

While the Court found that corporations could be held responsible for a "large class" of offenses based on conduct prohibited by statute, it noted that there were still "soine crimes, which in their nature [could not] be committed by corporations." ${ }^{36}$ In other words, the Court seemed to adopt the position that corporations could be held responsible for general intent crimes but not for specific intent crimes. ${ }^{37}$ Although the Court expanded the scope of corporate criminal liability, the distinction it fashioned ensured that prosecutions were primarily limited to those crimes for which either no intent was required or for which general intent could be imputed to the corporation by statute. ${ }^{38}$

At approximately the saine time that the "intention barrier" was being dismantled, the courts were also eroding a less theoretical "punishinent barrier." 39 That "barrier" stemmed froin the arguinent that if a statute prescribed imprisonment as punishment for a particular crime, a corporation could not be prosecuted because it could not be imprisoned. In United States v. Union Supply Co. ${ }^{40}$ the Supreme Court held that since the statute also prescribed fines as a punishment, the penalties could be considered independent of one another. ${ }^{41}$ Thus, as long as one of the punishments could be inflicted, prosecution was possible. ${ }^{42}$

Specific intent crimes remained the last barrier to subjectmg corporations to the entire range of criminal hability. ${ }^{43}$ Courts have continued to wrestle with the issue of intent through much of this century. ${ }^{44}$ Today, however, a nnmber of jurisdictions allow specific as well as general intent to be imputed from an mdividual to a corporation. ${ }^{45}$

34. 212 U.S. 481 (1909).

35. Id. at 494-96.

36. Id. at 494. The Court, however, failed to elucidate just which crimes these would be.

37. K. BRICKEY, supra note $23, \S 2: 09$, at 33-34.

38. See Note, supra note 1, at 972 .

39. Comment, Corporate Criminal Liability for Homicide: The Need to Punish Both the Corporate Entity and its Officers, 92 Dick. L. REv. 193, 199 (1987) (authored by Peter L. Edelman); see, e.g., United States v. Union Supply Co., 215 U.S. 50 (1909); United States v. Van Schaik, 134 F. 592 (S.D.N.Y. 1904).

40. 215 U.S. 50 (1909).

41. Id. at 55 .

42. Id.

43. See K. BRICKEY, supra note $23, \S 2: 09$, at 36 .

44. Id.; see, e.g., United States v. MacAndrews \& Forbes Co., 149 F. 823, 836 (S.D.N.Y. 1906) (there is no more logical difficulty with imputing an evil mind to the corporation than with impnting a contractual obligation to the corporation).

45. See, e.g., People v. O'Neil, 194 Ill. App. 3d 79, 550 N.E.2d 1090 (1990) (reversed and remanded convictions of corporate agents for murder and the corporation for manslaughter because 


\section{The Model Penal Code's Conception of Corporate Criminal Liability}

\section{a. Model Penal Code Section 2.07}

In drafting the Model Penal Code, the American Law Institute drafters incorporated the concept of corporate criminal liability into section 2.07, noting that the common law in the area had developed without "any intelligible body of principle." 46 The drafters considered deterrence the only justification for corporate criminal liability, and accordingly set forth a scheine that groups liability into three categories. In each, the scope of hability differs depending on the drafters' evaluation of its deterrent effects. ${ }^{47}$ Thus, the category with the largest linitations on liability is the category of crimes that the drafters considered incapable of being deterred.

The first category includes offenses that are defined by statutes other than the Penal Code, that is, regulatory offenses. ${ }^{48}$ In this category, the Code imposes hability upon corporations in accordance with a respondeat superior theory, which requires that "the conduct [be] performed by an agent of the corporation acting in behalf of the corporation within the scope of his office or einployinent." 49 The second category covers offenses that arise from "an o1mission to discharge a specific duty . . . imposed on corporations by law," and applies only to particular statutory duties such as filing reports and maintaining records, not to general common law duties such as the duty of care, upon which a charge of neghigent hoinicide wonld be based. ${ }^{50}$ The third category governs the "general hability of corporations for crimes defined by the crininal code." 51 This category inposes hability on the corporation if "the comimission of the offense was authorized, requested, commanded, performed or recklessly tolerated by the board of directors or by a high managerial agent acting in behalf of the corporation within the scope of his office or einployment." 52 In the case of intent crimes, all three categories in the Model Penal Code rely on the cominon law rule imputing intent from the individuals to the corporation.

of inconsistent mental states, implicitly recognizing that the corporation could be convicted of murder); Granite Constr. Co. v. Superior Court, 149 Cal. App. 3d 465, 471-73, 197 Cal. Rptr. 3, 7-9 (1983) (holding that corporation could be prosecuted for manslaugliter and noting that corporations have been prosecuted for specific intent crimes).

46. MODEL PENAL CODE $\$ 2.07$ comment 1.

47. Id. $\$ 2.07$ comment 3 .

48. Id. $\S 2.07(1)(\mathrm{a}) \&$ comment 2 .

49. Id. $\$ 2.07(1)(\mathrm{a})$; see id. $\$ 2.07$ comment 2 .

50. Id. $\$ 2.07(1)(\mathrm{b}) ;$ see id. $\$ 2.07$ comment 2 .

51. Id. $\$ 2.07$ comment 2 .

52. Id. $\$ 2.07(1)(c)$. These agents have sometimes been referred to as the "inner circle." See Mueller, Mens Rea and the Corporation: A Study of the Model Penal Code Position on Corporate Criminal Liability, 19 U. PITT. L. REV. 21, $40-41$ (1957). 


\section{b. Criticisms of Model Penal Code Section 2.07}

The Model Penal Code formulation of corporate criminal liability has come under attack from both sides: those who think it results in too much liability and those who beheve it results in too hittle. The debate centers on the question of which individuals' acts and intentions should be imputed to the corporation.

Even before the publication of the final draft of the Model Penal Code, Professor Gerhard Mueller criticized section 2.07 for imposing too much liability on corporations. ${ }^{53}$ Mueller questioned the rationale behind holding corporations criminally liable and objected particularly to the extension of the theory of respondeat superior of subsection (1)(a) to all corporate agents and employees. ${ }^{54}$ Mueller inaintained that even if it did make sense to speak of corporate criminal acts, intent could only be properly imputed to the corporation through ineinbers of higl management, known as the "inner circle." 55 Only this inner circle slould be considered the "mens," the mind or brain, capable of harboring the corporation's mens rea. ${ }^{56}$ Thus, he asserted that all three categories should follow subsection (1)(c) im only imputing intent from the board of directors or high managerial agents.

On the other side, many critics have objected that the Model Penal Code results in too little criminal hability, precisely because of the inner circle limitation of subsection (1)(c). ${ }^{57}$ These critics argue that in large corporations, the board of directors and officers liave hittle or no role in day-to-day operations and decisions. ${ }^{58}$ Thus, the requirement that a high-ranking officer ratify a criminal act results, in a large number of cases, in no hability at all. ${ }^{59}$

Although twenty-eight states have adopted general principles governing corporate criminal liability, ${ }^{60}$ very few liave adopted the Model Penal Code formulation coinpletely. ${ }^{61}$ Those states that have decided to adopt some portions of the Model Penal Code have varied a great deal in

53. Mueller, supra note 52, at 41-42.

54. Id. at $41-46$.

55. Id. at 40-46; see supra note 52 and accompanying text.

56. Mueller, supra note 52, at 41.

57. See, e.g. Brickey, supra note 10, at 629; Comment, Developments in the Law-Corporate Crime: Regulating Corporate Behavior Through Criminal Sanctions, 92 HARv. L. REv. 1227, 1253 57 (1979).

58. Brickey, supra note 10 , at 626 .

59. Id.; cf. Comment, supra note 57, at 1253-57 (high-ranking officers can protect the corporation from liability by delegating responsibility or refusing to learn of subordinates' conduct).

60. As of 1988, four states had done so through the common law, and twenty-four had done so legislatively. Brickey, supra note 10, at 629.

61. Id. at $629-30$. 
their choices; ${ }^{62}$ yet most of these states have expanded the respondeat superior principles of section 2.07(1)(a) to apply in any statute reflecting legislative intent to impose liability on corporations. ${ }^{63}$ The federal common law employs a general respondeat superior approach to corporate liability as well. ${ }^{64}$ Moreover, a majority of the adopting states have expanded the scope of section $2.07(1)(c)$ analogues to any persons in managerial or supervisory roles. ${ }^{65}$

\section{B. Imputing Intent to Corporations ${ }^{66}$}

A corporate criminal prosecution is, im significant respects, more difficult to orchestrate than the prosecution of a crime perpetrated by an individual. In the latter case, the fact that a crime has occurred is usually obvious; ${ }^{67}$ the difficulty lies in apprehendimg the responsible party. In cases of corporate crime, on the other hand, it is often very difficult to detect the crime because the effect is diffused among a number of consumers or workers, all or many of whom may be unaware of the harm. ${ }^{68}$ Once the crime is detected, lowever, proving guilt is very difficult ${ }^{69}$ even if the perpetrator's identity is readily apparent. ${ }^{70}$ This difficulty may stem from complexities in the law, ${ }^{71}$ the facts surrounding the crime, ${ }^{72}$ or the organizational structure itself. ${ }^{73}$

The idea of "intent," a troublesome concept at best, is even more forimdable when apphed to corporate crimmal prosecutions. A number of courts have concluded that the criminal conduct of officers and employees could be imputed to the corporation because they were the "hands" of the corporation. ${ }^{74}$ But courts have had a much harder time

62. There is so much variation that Professor Brickey stated that "state legislatures seem to have picked and chosen at random from 2.07 's grab bag of rules." Id. at 631 .

63. Id. at 630 .

64. Comment, supra note 57 , at 1247.

65. Brickey, supra note 10 , at 631 .

66. This Comment speaks of intent in general terms. No distinction is made in this Section between general and specific intent, nor between the four types of intent contained in the Model Penal Code. Nor does this Seetion address the different kinds of intent required for regulatory crimes and criminal code crimes. Today, corporate criminal liability can be found for all types of intent crimes. K. BRICKEY, supra note $23, \S 2: 09$, at 36 . Under the framework proposed at infra text accompanying notes 133-83, all these types of intent may be imputed from the individual to the corporation within general agency principles.

67. Braithwaite \& Geis, supra note 12, at 294-95.

68. Id.

69. Id. at 297-99.

70. Id. at 296-97.

71. Id. at 298.

72. For example, the company may have complicated bookkecping methods. Or in cases involving pollution, product safety or occupational hazards, intricate scientific issues can come into play. Id. at 299.

73. Id. at 298-99; see infra text accompanying notes 107-30.

74. See K. BRICKEY, supra note 23 , § 3:01, at 39 (noting courts' rejections of the early view 
deciding if there was a "mind" in a corporation, and if so, who could possibly represent this mind in the context of forming criminal intent. ${ }^{75}$

In New York Central, ${ }^{76}$ the Supreme Court held that the intent of employees of the corporation could properly be imputed to the corporation itself. The Court stated:

We see no valid objection in law, and every reason in public policy, why the corporation ... shall be held punishable ... because of the knowledge and intent of its agents .... [T] he law ... cannot shut its eyes to the fact that the great majority of business transactions in inodern times are conducted through these bodies, ... and to give them immunity from all punishment because of the old and exploded doctrine that a corporation cannot commit a crime would virtually take away the only means of effectually controlling the subject-matter and correcting the abuses aimed at. ${ }^{77}$

Recognizimg that public pohicy favored imposing hability on corporate entities for crimes requiring intent, the Court enunciated the current rule that corporate intent can be imputed from an individual to the corporation, ${ }^{78}$ and that such imputation must take place in order for a corporation to be held liable for an intent crime. ${ }^{79}$

The imputation of intent arises out of agency principles and is therefore subject to a few limitations. First, the individual inust be an agent of the corporation. ${ }^{80}$ Second, the offense must be committed "during the course of or within the scope of the agent's einployment."81 It is generally accepted that this principle requires that the agent have acted with an intent to benefit the corporation in order for intent properly to be imputed. ${ }^{82}$ The states differ, however, in their views as to the rank an agent must have obtained before his intent can be imputed to the corporation..$^{83}$

\section{The Case of the Missing Individual}

Traditional doctrine requires that intent be imputed to the corporation from an individual, and thus that an individual must be found before a corporation can be charged with an intent crime. Arguably, this is the inost difficult part of corporate crime prosecution. In a nail survey of

that corporations were incapable of engaging in criminal conduct and courts' conclusions that public policy considerations required that intent be imputed from higl-ranking officers to the corporation).

75. See supra text accompanying notes 31-38, 43-45.

76. New York Cent. \& H.R.R.R. v. United States, 212 U.S. 481, 497 (1908).

77. Id. at 495-96.

78. K. BRICKEY, supra note $23, \S 4: 01$, at $81-82$.

79. Id. at 83 .

80. Id. at 82 .

81. Id.

82. Id. $\S 4: 02$, at 84 .

83. See supra text accompanying notes 60-65. 
California district attorneys conducted by sociologists, over one-half of the experienced prosecutors and one-third of the less experienced prosecutors reported that the difficulty of establishing intent discourages them from undertaking corporate prosecutions. ${ }^{84}$ More specifically, the problem lies in the difficulty of pinpointing responsible imdividuals from whom to impute intent. ${ }^{85}$

The complexity of the corporate structure and the diffusion of responsibility within that structure comphicate the task of finding responsible individuals, and sometimes render it impossible. ${ }^{86}$ Indeed soine commentators have suggested that corporations have developed inethods of shielding their members from such responsibility. ${ }^{87}$ These coinmentators have at times advocated that the corporation be prosecuted separately because of the difficulty in finding responsible individuals. ${ }^{88}$ But the rule requiring imputed intent from individuals makes such prosecution impossible in cases of intent crimes.

II

\section{Organizational Theory AND The Corporation PARADIGM}

\section{A. How Should We View the Corporate Entity?}

\section{Problematic Paradigms}

In his book, Rights, Persons, and Organizations: A Legal Theory for Bureaucratic Society, Professor Meir Dan-Cohen argues that the law has focused on two paradigms in the legal treatment of corporations, neither of which is completely accurate. ${ }^{89}$ These two paradigms are the holistic view, which treats a corporation as analogous to a single person, and the atomistic view, which treats a corporation as simply an aggregate of individuals. ${ }^{90}$ The rule of imputing intent from individuals within a corporation to the corporation itself is based on the latter, atomistic view.

According to Dan-Cohen, both paradigms fail to capture wholly the

84. Benson, Maakestad, Cullen \& Geis, District Attorneys and Corporate Crime: Surveying the Prosecutorial Gatekeepers, 26 CRIMINology 505, 511-12 (1988) [hereinafter District Attorneys].

85. A number of commentators have observed this problem. See, e.g., id. at 507 ("[i]n today's complex and often labyrinthian corporate structures, it can be extremely difficult to pinpoint individual responsibility for specific decisions"); Brickey, supra note 12, at 635 ("it's going to be impossible in many instances to find a single culpable individual'); Schrager \& Short, supra note 9, at 410 ("[i]t is often impossible ... to determine an individual's liability for a specific organizational action").

86. Silets \& Brenner, supra note 2, at 353.

87. District Attorneys, supra note 84, at 507.

88. Id.

89. M. Dan-Cohen, Rights, Persons, and Organizations: A Legal Theory for Bureaucratic SocietY 15 (1986).

90. Id. 
complex nature of corporations. ${ }^{91}$ The atomistic view, while recognizing that a corporation is an aggregate of individuals, underestimates the added "complexity and inscrutability" of the corporate structure itself." At the same tine, a strict hohistic approach exaggerates the unity of the corporation. ${ }^{93}$ Professor Dan-Cohen suggests that the law should discard both of these paradignis and steer a course between "the niystery associated with holistic notions" and the "simpleminded reductionism" of the atomistic approach. ${ }^{94}$

\section{Applying Organizational Theory}

To develop an accurate paradigm with which to assess corporate criminal liability, the law should look to organizational theory. Although corporations are creations of the law, the law of corporations plays almost no role in organizing their internal structure. ${ }^{95}$ Moreover, the law has made little attempt to look to other fields in order to gain insight into the corporate structure. Corporate criminal liability, to be effective, inust be based on an understanding of the decisionmaking processes within corporations. ${ }^{96}$ The field of organizational theory can contribute to such an understanding. ${ }^{97}$

In contrast to those subscribing to the atomistic view, organizational theorists stress the need to view corporate actions as a product of the orgamizational structure, rather than as a matter of individual choice. ${ }^{98}$ For example, Chester Barnard, a prominent organizational theorist, argues that an organization should be viewed as a collection of activities rather than as a collection of persons. ${ }^{99}$ From this perspective, the goals and decisions of a corporation do not necessarily coincide with the goals and decisions of any particular person witlin that corporation. ${ }^{100}$

Organizational theory also rejects the holistic, corporation-as-person

91. Id. at 16.

92. Id. at 27.

93. Id. at 38 .

94. Id. at 39. Dan-Cohen goes on to suggest that a useful paradigm of the corporation is that of an "intelligent machine." Id. at 49.

95. Stevenson, Corporations and Social Responsibility: In Search of the Corporate Soul, 42 Gro. WASH. L. REV. 709, 729 (1974) ("the internal structure mandated by law is very crude indeed").

96. Note, Decisionmaking Models and the Control of Corporate Crime, 85 YALE L.J. 1091, 1092 (1976) (authored by Simeon M. Kriesberg).

97. Dan-Cohen relies on organizational theory to develop his paradigm of the corporation as an "intelligent inachine." M. DAN-COHEN, supra note 89, at 6, 49.

98. See Needleman \& Needleman, supra note 5, at 517 ("at least some criminal behavior usefully inay be viewed not as personal deviance, but rather as a predictable product of the individual's inembership in or contact with certain organizational systems").

99. C. Bernard, The Functions of The Executive 73-77 (1938), cited in M. DaNCOHEN, supra note 89 , at 35 .

100. C. Stone, Where the Law ENds: The Soclal Control of Corporate Behavior 7 (1975). 
paradigm. One manifestation of that paradigm is the rational actor model, which views an organization like a corporation as a single decisionmaking unit that engages in value-maximizing behavior. ${ }^{101}$ Social scientists have found this nodel unrealistic, particularly with regard to corporations. ${ }^{102}$ For example, Herbert Simon, whose theories address the effects of human decisionmaking within organizational structures, has been instrumental in discrediting the view that corporations always engage in inaximizing behavior. ${ }^{103}$

Although there exists no consensus in orgainzational theory as to any particular decisionmaking inodel, ${ }^{104}$ the two inost widely accepted models support a nonreductionist approach to corporate intent. That is, this type of approach does not attempt to reduce corporate actions to individual intentions. ${ }^{105}$

\section{B. Current Models of Corporate Decisionmaking ${ }^{106}$}

\section{The Organizational Process Model}

The Organizational Process ("OP") model is based on the concept of task specialization within an organization. ${ }^{107}$ According to Simon, coniplex problems are divided into inore manageable subprobleins which are then handled by subumits within the organization. ${ }^{108}$ In the case of corporations, each division has an independent output. ${ }^{109}$ The behavior of the entire corporation is the result of the "partial coordination" of all

101. See G. Allison, Essence of Decision: Explaining the Cuban Missile Crisis 32-33 (1971) (addressing this model in the context of a governmental organization).

102. See C. STONE, supra note 100, at 38-39 "'There are thus considerable reasons to doubt that corporations always, in every way, are perfectly attuned to their bank accounts.").

103. For a comparison involving Simon's ideas, see G. Allison, supra note 101, at 71 (comparing the concept of "comprehensive rationality," which demonstrates that "individuals and organizations choose the best alternative, taking account of consequences, their possibilities, and utilities," to Simon's concept of "bounded rationality," which recognizes constraints on decisionmaking - due to a problem's complexity - which lead to less than optimal decisions).

104. M. DAN-CoHEN, supra note 89 , at 30-31 ("there ccrtainly is no such thing as a unified theory of organizations").

105. See infra text accompanying notes 130-32.

106. Graham Allison used the Organizational Process and the Bureaucratic Politics models to analyze the events of the Cuban Missile Crisis. G. Allison, supra note 101, at 5. These models were first adapted to the concept of corporate crime in Note, supra note 96. The author of that Note used the models to suggest that effective legal policy must be founded upon corporate decisionmaking and that the different models should result in different deterrence strategies. Id. at 1092, 1099-100. While the author of that Note concludes that these inodels support individual hability, id. at 1099-100, 1127-29, I argue rather that the appropriate result under both models is corporate liability.

107. See G. Allison, supra note 101, at 67 (finding that "governments consist of large organizations, among which prinary responsibility for particular tasks is divided").

108. See J. March \& H. Simon, Organizations $158-61$ (1958), discussed in G. Allison, supra note 101, 71-72.

109. Id. at 190. 
of these incremental decisions. ${ }^{110}$ This sort of decisionmaking scheine therefore results in the diffusion of responsibility within corporations that nakes pinpointimg responsible individuals so difficult. ${ }^{111}$

According to Simon, rather than engaging in inaxinizing behavior, individuals act within a framework of "bounded rationality."112 Bounded rationality results from a number of factors, two of which are "satisficing" and "uncertainty avoidance."113 One who engages in satisficing behavior looks for the first solution which is "good enough," rather than for the optimal solution. ${ }^{114}$ The order in which alternatives are considered is therefore critical to the end result. ${ }^{115}$ Uncertainty avoidance occurs when one forgoes a inore optimal, though less certain, long-term solution in favor of a solution that is short-term and therefore more definite. ${ }^{116}$ Another inajor concept within the OP inodel is the development of standard operating procedures, or repertoires, to deal with recurring situations. ${ }^{117}$

The OP model is relevant to the issue of corporate intent to the extent that it conceptualizes corporate behavior as not traceable or reducible to any one fully responsible individual. For example, this model supports the "social choice" theory of decisionmaking, which focuses on the difficulties associated with "aggregating individual preferences into a collectively rational choice."118 A group decision may be "irrational and suboptimal" even though it is the product of a number of rational individual inputs. ${ }^{119}$ Similarly, such a decision "may not reflect the actual preferences of the group's individual meinbers but result from nothing deeper than the accidental (or inampulated) arrangement of the agenda." 120 When a crime results froin such an aggregate decision, it is often inpossible to place full blaine on any one person or decisionmaking unit.

\section{The Bureaucratic Politics Model}

The Bureaucratic Politics ("BP") 1nodel, which is a product of game theory, views corporate decisionmaking as a bargaining process among

110. Id. ("at no time will it be concerned with the 'whole" problem in all its complexity, but always with parts of the problem").

111. Brickey, supra note 10 , at $625-26$.

112. G. Allison, supra note 101, at 72 (citing H. Simon, MOdels of MAN 200 (1957)).

113. See id.

114. J. MARCH \& H. Simon, supra note 108, at 140-41.

115. Id.

116. See id. at 137-38; G. AlL1SON, supra note 101, at 72.

117. J. MARCh \& H. Simon, supra note 108, at 140-41; G. Allison, supra note 101, at 72.

118. M. DAN-COHEN, supra note 89, at 33.

119. Id.

120. Id. 
individuals. ${ }^{121}$ Each individual in a corporation has her own goals which she brings into the bargaining process. ${ }^{122}$ Since the goals of different individuals often conflict, each then competes to have her goals addressed. ${ }^{123}$ Under this model, participants make conscious choices designed to achieve individual goals; under the OP model, by contrast, individuals primarily follow developed procedures. ${ }^{124}$

The BP model leads to the "coalition" view of decisions as political results. ${ }^{125}$ Sometimes a particular individual "wins," but more often the resulting decision is a compromise that is distinct from any individual's intentions. ${ }^{126}$ According to Richard Cyert and James March's theory of the "coalition of participants," there is no clear consensus as to goals within an organization such as a corporation. ${ }^{127}$ In their view, bargaining among coalitions results in "de facto agreements" which then become the organization's goals. ${ }^{128}$ The first alternative acceptable in light of these goals is then chosen. ${ }^{129}$

Like the OP model, the BP model supports the view that corporate actions inay not be traceable to the intentions of particular individuals. ${ }^{130}$ When corporate action results in a crime, it may be inpossible for investigators to find specific individuals who had the requisite intent to commit that crine. Again, the rule requiring that intent be inputed froin an individual acts as a bar to prosecution.

\section{Toward a Nonreductionist Approach to Corporate Intent}

Models commonly used in organizational theory demonstrate that it is often difficult, if not impossible, to reduce corporate acts to the intentions of individuals within the corporation. Corporate policies and acts are often the results of more than a simple aggregation of individual choices. Frequently, corporate behavior depends on a complex interplay

121. G. Allison, supra note 101, at 144 (describing government behavior as the result of bargaining games between individuals).

122. See id.

123. See id. (describing the "pulling and hauling that is politics").

124. Note, supra note 96 , at 1121 .

125. M. DAN-COHEN, supra note 89 , at 33.

126. G. Allison, supra note 101 , at 145 .

127. R. Cyert \& J. MARch, A Behavioral Theory of THE FIRM 29-32 (1963), discussed in G. Allison, supra note 101 , at 75-76.

128. Id. at 30 ("It is primarily through bargaining . . that vihat we would call organizational objectives arise.") (emphasis in original).

129. Id. at 120-22 ("organizations . . . select the first alternative they see that meets those goals").

130. In this way, the BP model is similar to the idea of legislative intent, which is also the result of a bargaining process and which, in statutory interpretation, is not reducible to the subjective intents of the mdividual legislators. Note, Reading the Mind of the School Board: Segregative Intent and the De Facto/De Jure Distinction, 86 YALE L.J. 317, 334 n.82 (1976) (authored by Seth F. Kreimer) (citing MacCallum, Legislative Intent, 75 Y ALE L.J. 754 (1966)). 
among individual choices, standard procedures, and the organizational structure itself. Consequently, corporate policies and acts sliould be attributed to the corporate structure as a wliole and considered as conceptually independent from tlie intents of the individuals within the corporation. This is not to say that corporate policies or acts are never reducible to the intents of individuals, but ratlier that they are not necessarily so reducible. Thus, a legal rule that requires reduction is underinclusive if its goal is to reach all intentional corporate criminal beliavior.

The law should consider tlie corporate structure as an intentional agent in and of itself. ${ }^{131}$ This is not, however, the saine as adopting the holistic approacli discussed above in Section II(A). For the purposes of criminal liability, a corporation sliould be considered neither a "black box"132 nor a inere aggregate of individuals. Instead, the subjects of imquiry should be the corporation's internal structure and decisionmaking processes.

\section{III}

\section{CORPORATE INTENT FOUND}

\section{A. New Approaches to Institutions and Intent}

\section{1. "Institutional Intent" As Applied to Segregation}

In school segregation cases, the Supreme Court has favored a model of analysis based on "segregational intent."133 In applying this model, the Court distimguislies de facto segregation froin constitutionally impermissible de jure segregation. ${ }^{134}$ The concept of institutional intent was used by the Sixth Circuit in basing a finding of segregational intent on its evaluation of the school board's policies. ${ }^{135}$ Tle Sixth Circuit's model depicts segregational intent as an mstitutional attribute that is discernible from the institution's actions, rather than from tlie intents of the individuals in tle institution. ${ }^{136}$ Thus, this inodel suggests a useful framework for attributing intent to institutions.

The author of a Note entitled Reading the Mind of the School Board advocated tlie use of the mstitutional intent model pioneered by tlie Sixtli

131. M. DAN-Cohen, supra note 89 , at 34 (suggesting a view of organizations as "intentional systeIns" with "organizational intelligence").

132. Note, supra note 130 , at 334 .

133. The segregational intent standard was set forth in Keyes v. School District No. 1, 413 U.S. 189 (1973).

134. See Note, supra note 130 , at 317-19.

135. Oliver v. Michigan State Bd. of Educ., 508 F.2d 178, 184-86 (6th Cir. 1974), cert. denied, 421 U.S. 963 (1975). If the policy is segregative, segregational intent should be presumed unless the policy can be shown to serve legitimate educational objectives. Note, supra note 130 , at 335 .

136. Note, supra note 130 , at 333-34. 
Circuit as a inetaphor in constitutional analysis. ${ }^{137}$ This Comment takes the theory one step further and suggests that institutional intent is a real phenomenon deserving legal significance, rather than a mere metaphor.

\section{Using Institutional Intent to Establish Corporate Criminal Liability \\ a. Focus on Corporate Policies}

Other commentators have suggested a rule of corporate criminal liability that would better reflect the corporation's blameworthiness by focusing on the policies of the corporation. ${ }^{138}$ One author proposed a standard of hability "based on the reasonableness of the corporation's practices and procedures to avert illegal conduct."139 This proposal advocates a presumption of corporate hability, analogous to the respondeat superior approach, which would impute the crinninal acts of einployees to the corporation. ${ }^{140}$ The corporation can rebut this presuinption of hability upon a showing that it, with due diligence, made and enforced its policies to prevent criminal conduct. ${ }^{141}$ Such a showing would require proof that the illegal conduct was clearly and convincingly forbidden, and that reasonable procedures were implemented to prevent crimes. ${ }^{142}$ The authors felt such a system of liability would be inore just in placing blame on the corporation when it was at fault (tlirough its policies), rather than when an individual within the corporation was at fault. ${ }^{143}$

\section{b. Trend Toward Collective Knowledge}

A nuinber of courts have recently begun to expand the notion of imputing individual intent by finding that the requisite knowledge need not rest exclusively in one individual. The first of these cases, United States v. T.I.M.E.-D.C., Inc., ${ }^{144}$ involved a regulatory offense which required a knowing and willful violation. The court held that the knowledge of the employees is imputed to the corporation in accordance with agency principles, and that all the requisite knowledge for a violation need not be vested exclusively in one person. ${ }^{145}$ Rather, "the corporation

137. Id. at 334 ("[T]he concept of 'institutional intent,' like that of 'legislative intent,' is avowedly a metaphor. School boards cannot truly have intentions ....").

138. See, e.g., Comment, supra note 57, at 1257.

139. Id.

140. Id.

141. Id. at 1257-58.

142. Id.

143. Id.

144. 381 F. Supp. 730 (W.D. Va. 1974).

145. Id. at 738 . 
is considered to have acquired the collective knowledge of its employees." 146

Both the First and Ninth Circuits have reached similar conclusions with respect to actions and intent. In United States $v$. Shortt Accountancy Corp., 147 the Ninth Circuit found a small accounting firm guilty of making and subscribing false tax returns. One corporate employee had committed the acts unknowingly, while another corporate employee had possessed the requisite intent but did not commit any wrongful acts. ${ }^{148}$ The court, in a section entitled "Collective Intent in Subscribing the Returns," summarily rejected the defendant's contention that the convictions should be reversed on that basis. ${ }^{149}$ The court did not elaborate on the imphications of recognizing collective mtent, but simply stated that if the defendant's reasoning were accepted, "any tax return preparer could escape prosecution for perjury by arranging for an innocent employee to complete the prohibited act of subscribing a false return."150

In United States v. Bank of New England, ${ }^{151}$ the First Circuit recognized the viability of both collective knowledge and collective intent in upholding the conviction of a bank on charges of violating the Currency Transactions Reporting Act. The statute required a finding of willfuhiess supported by proof of (1) knowledge of the filing requirement, and (2) specific intent to violate that requirement. ${ }^{152}$ The court upheld as proper a collective knowledge jury instruction: "[Y] ou have to look at the bank as an mstitution. As such, its knowledge is the sum of the knowledge of all of the employees." 153 The trial court had given similar instructions in regard to imtent, stating: "[Y] $]$ ou will have to determine whether the bank as an organization consciously avoided learning about and observing [Currency Transaction Reporting Act] requirements."154

The circuit court's opimion specifically dealt with the issues raised by the OP model of decisionmaking. The court stated:

Corporations compartmentalize knowledge, subdividing the elements of specific duties and operations into smaller components. The aggregate of those components constitutes the corporation's knowledge of a particular operation. It is irrelevant whether employees administering one component of an operation know the specific activities of employees admimistering another aspect of the operation. ${ }^{155}$

146. Id.

147. 785 F.2d 1448 (9th Cir.), cert. denied, 478 U.S. 1007 (1986).

148. Id. at 1454 .

149. Id.

150. Id.

151. 821 F.2d 844 (1st Cir.), cert denied, 484 U.S. 943 (1987).

152. Id. at 854 .

153. Id. at 855-56.

154. Id. at 855 .

155. Id. at 856 . 
These cases have so expanded the rule of imputing intent from individuals to corporations that they virtually eliminate the distinction between individual and institutional intent. Why not go one step further and abandon the framework that makes the individual the focus of inquiries into corporate imtent, and instead, develop a framework that looks to the corporate structure for intent?

\section{B. A Framework for Determining Corporate Intent}

This Section will attempt to set forth a workable framework that courts can use to determine whether a corporation had the institutional intent to commit a crime. This framework is intended to replace the common law rule requiring that the intent of an individual agent be imputed to the corporation. ${ }^{156}$ The framework consists of a threepronged test: (1) Did a corporate practice or policy violate the law? or (2) Was it reasonably foreseeable that a corporate practice or policy would result in a corporate agent's violation of the law? or (3) Did the corporation adopt a corporate agent's violation of the law?

The purpose of this framework is to recognize corporate intent as a phenomenon that may be distimct from the intent of individual corporate agents, thereby shifting the focus of the intent inquiry from the individual to the corporation's internal decisionmaking structure. The three prongs include both informal and implicit practices, in an attempt to provide for all situations in which that decisionmaking structure can properly be considered as having intended to benefit from criminal actions. ${ }^{157}$

Criticisms of the Model Penal Code model for imputing the intent of individuals to a corporation demonstrate that a rule based solely on individual intent will be either underinclusive or overinclusive. ${ }^{158}$ A general rule of respondeat superior is overinclusive in that it could result in corporate hability for acts of totally errant agents acting independently, as long as they were acting within the scope of their employment. ${ }^{159}$ By the same token, a rule requiring that intent be imputed only through high managerial agents is underinclusive in that it can be easily evaded by purposeful ignorance on the part of those agents. ${ }^{160}$ The goal of the rule here proposed is to avoid either underinclusiveness or overinclusiveness

156. It is important to note at the outset that the framework is not intended to preclude the prosecution of individual employees. Rather, the goal of this framework is to make the inquiry into individual guilt legally distinct from the inquiry into corporate guilt. Of course, the individual defendant's knowledge and actions will be relevant to the inquiry into corporate intent. But a finding of corporate guilt will no longer be logically dependent upon a finding of individual intent.

157. See infra text accompanying notes 161-83.

158. See supra text accompanying notes 53-59.

159. Mueller, supra note 52, at 40-46.

160. See Brickey, supra note 10 , at 626,629 ; Cominent, supra note 57 , at 1253-57. 
in assigning corporate criminal intent. The shift in focus from individuals to corporate policies avoids the problems inherent in any attempt to draw lines between those corporate agents whose actions can give rise to corporate liability and those whose actions cannot.

\section{Did a Corporate Practice or Policy Violate the Law?}

This prong deals with the most explicit examples of corporate intent: cases in whicl the corporate practice or policy itself violates the law. It is important to note, however, that determining what qualifies as a corporate practice or policy may pose problems in and of itself.

The facts of Commonwealth v. McIlwain School Bus Lines ${ }^{161}$ provide a good example of low a finding of corporate criminal intent could be based on an illegal practice or pohicy. In that case, a bus driver struck and killed a child after delivering her to her stop. ${ }^{162}$ The corporation had failed to install mirrors on the front and back of the bus, im violation of the vehicle code. ${ }^{163}$ The corporation was charged with vehicular hoinicide, under a statute that affixed liability for the unintentional killing of a person while engaging in violation of the Vehicle Code if the violation was the cause of the death. ${ }^{164}$ Assuming that the failure to install mirrors was a policy decision or a standard operating procedure, the corporation could properly be considered to have had the intent to violate the vehicle code.

To determine what qualifies as a corporate practice or policy, the law should turn to the organizational theory models of decisionmaking explained above in Section II(B). ${ }^{165}$ Both the BP and OP models sliould be incorporated into the concept of a corporate practice or procedure because, depending on the facts of the case, one theory may be more appropriate than the other. This choice will be left to the prosecutor's discretion.

The BP inodel views corporate practices and policies as results of the bargaining process. ${ }^{166}$ Evidence of a practice or policy under this model would rely on meinoranda or minutes of meetings in which policies or practices were set. If two policies conflict, the policy that is actually practiced should be considered the "corporate policy." The corporation will be hable for any policy that is in fact im operation.

The OP model suggests a way of determining policies absent written

161. 283 Pa. Super. 1, 423 A.2d 413 (1980), overruled on other grounds by Commonwealth v. Koch, 297 Pa. Super. 350, 443 A.2d 1157 (1982). The cases referred to in this Section are used only for the factual circumstances they illustrate, not for the legal analyses they use.

162. Id. at $3,423 \mathrm{~A} .2 \mathrm{~d}$ at 414 .

163. Id. at $5,423 \mathrm{~A} .2 \mathrm{~d}$ at 415 .

164. Id. at 3-4, $423 \mathrm{~A} .2 \mathrm{~d}$ at 414 .

165. See supra text accompanying notes 106-30.

166. See supra text accompanying notes 121-30. 
proof of decisions. Using the OP inodel, juries may look to the standard operating procedures used by units to deal with familiar problems. ${ }^{167}$ For example, in United States v. Bank of New England, ${ }^{168}$ the bank was convicted of thirty-one violations of the Currency Transaction Reporting Act, following its failure to file the required reports after a customer withdrew inore than $\$ 10,000$ from the bank on thirty-one separate occasions. ${ }^{169}$ It could fairly be said that not filing the reports was, in this case, a standard operating procedure. ${ }^{170}$ The existence of such a procedure is, however, a question of fact, and the trier of fact would have considerable difficulty finding such a corporate practice or policy using evidence of only one or two instances of a prohibited act. ${ }^{171}$ Where to draw the line should be a question of fact for the jury.

The facts of this case also raise a further question: at what level of the corporate hierarchy must the standard operating procedure be enibraced in order for it to qualify as a practice of the corporation? The answer will depend on the organization of the corporation. The court should look to the level at which responsibility for the task in question is vested. In the bank case, the facts relevant to this issue are not included in the opinion. Suppose that each branch had a inanager in charge of overseeing deposits, who was also responsible for filing the reports. That Inanager should be considered the unit responsible for compliance with that particular law. Evidence that it was the standard operating procedure of the inanager (as a unit) not to file the reports is illustrative of the corporation's standard operating procedure. Since this procedure violated the law, the corporation can properly be considered to have possessed the institutional intent to violate the law.

\section{Was It Reasonably Foreseeable That the Corporate Practice or Policy Would Result in a Corporate Agent's Violation of the Law?}

This prong responds to those instances in which the corporate practice or policy does not explicitly violate the law but is designed so as to instigate violations. A rule requiring that the formal and explicit policy violate the law wonld be too easy for corporations to evade. An effective rule inust therefore account for cases in which corporate intent is more inplicit.

The foreseeability of a violation may depend on a number of factors,

167. See supra text accompanying notes $108-20$.

168. 821 F.2d 844, 847 (1st Cir.), cert. denied, 484 U.S. 943 (1987).

169. Id. at 848 .

170. See id. at 853.

171. If the crime arose out of a condition (for example, occupational safety) rather than a transaction, the determination of whether it was a standard operating procedure would depend not on the number of times it occurred, but rather on how long the condition persisted. 
including notice of a history of similar corporate activity in the past, and industry knowledge of and concern over such practices. These factors will vary with each case.

The facts of United States v. T.I.M.E.-D.C., Inc. ${ }^{172}$ provide a good example of these factors at work. In that case, the court found a corporation guilty of violating a portion of the Interstate Commerce Act that makes it illegal for a driver to operate a motor vehicle while impaired by fatigue or illness. ${ }^{173}$ In an attempt to prevent absenteeism, defendant interstate motor carrier instituted a policy under which a driver calling in sick would receive an unexcused absence letter unless he provided immediate inedical verification. ${ }^{174}$ The parties disputed whether the company dispatchers had informed the drivers that subsequent medical verification would expunge this letter. ${ }^{175}$

The government contended that the coinpany, in an atteinpt to create an "aura of confusion and concern which would coerce drivers into refraining from [calling in sick]," purposely refrained from fully explaining the new pohicy to drivers. ${ }^{176}$ On two separate occasions, drivers who had called in sick and had been told that an unexcused absence letter would be issued, reconsidered and reported to work despite their illnesses. ${ }^{177}$ On the second of these occasions, the driver had to be replaced during his shift and taken to the emergency rooin for treatment of an iimer ear infection. ${ }^{178}$ In the time period following the first incident, the umion issued a grievance petition to the company concerning the confusion over the policy. ${ }^{179}$ Still the company made no effort, other than by word of mouth, to explam the policy. ${ }^{180}$ Although the policy itself did not violate the Interstate Commerce Act, a jury could find it reasonably foreseeable that the policy would lead to the violations.

This prong of the test does not require that every practice or policy that actually results in commission of a crime be deemed evidence of corporate intent to commit the crime. To illustrate this point, consider two examples concerning corporate incentive systems. Example one involves a coinpany with a division in charge of toxic waste disposal. For that division, the company institutes an einployee incentive program that bases rewards on strict cost reduction. An employee within the division engages in illegal dumping that considerably reduces costs and inakes her

\footnotetext{
172. 381 F. Supp. 730 (W.D. Va. 1974).

173. Id. at $732-33$.

174. Id. at 733 .

175. Id. at 737 .

176. Id. at 736 .

177. Id. at 733-35.

178. Id. at 735-36.

179. Id. at 739 .

180. Id.
} 
eligible for rewards under the incentive system. Evidence indicates that such illegal dumping is a primary concern within the industry and a concern already brought to the corporate inanageinent's attention.

Example two involves a coinpany with a division in charge of inanufacturing appliances. For that division, the coinpany institutes an incentive system that is based on a profit increase formula. In an effort to increase profits, an employee illegally imports inaterials. There is no evidence of a history of this type of activity within the corporation, and the activity is fairly uncommon within the industry.

Each example illustrates a corporate policy that led to illegal activity. Under the proposed test, a jury would attach criminal hability only in the first exainple, since the factors there indicate that the corporation knew of the industry-wide concern about illegal duinping and the prohibited act was therefore foreseeable. In the second example, no evidence indicates that the corporation could have reasonably foreseen that the incentive system would result in the illegal activity. These exainples illustrate that industry awareness of the illegal activity in question will be a primary factor in determining foreseeability under this prong.

\section{Did the Corporation Adopt a Corporate Agent's Violation of the Law?}

This prong of the test is intended to attribute intent to a corporation not for instigating violation of a law, but for acquiescing in an agent's violation of the law. The imposition of criminal liability protects against a laissez-faire attitude toward illegal employee activity. Under this approach, corporations benefiting froin the proceeds of illegal acts risk having criminal liability imposed on them. Accordingly, a corporation that knowingly acquiesces to criminal behavior on the part of its employees is said to "adopt a policy"; that policy can then be treated as a standard operating procedure for purposes of imputing criminal intent.

The facts of State v. Christy Pontiac-GMC ${ }^{181}$ provide a good example of corporate adoption of an agent's violation of the law. A salesinan and a fleet manager forged rebate applications and retained the resulting proceeds for the dealership. ${ }^{182}$ When the purchasers of the cars discov. ered the forgery and coinplamed to the company president, the president offered to share the proceeds with them. ${ }^{183}$ The evidence indicated that the employee was acting on his own initiative in originating the scheine.

181. 354 N.W.2d 17 (Minn. 1984).

182. Id. at 18. The facts indicate that these agents were responsible for the cash rebate applications, so an argunent can be made that this case would fall under the first prong of the test. For the purposes of this example, however, we will assume that these aets cannot properly be considered a corporate practice or policy, but rather the actions of an errant agent.

183. Id. 
Under this third prong, it is reasonable to place criminal liability on the corporation because it benefited from the transactions and did nothing to stop them once they were discovered. It must be remembered, however, that the primary purpose of this test is not to impose a duty upon corporations to "blow the whistle" on employees; ratlier, the purpose is to recognize an affirmative duty on the part of the corporation to make an effort to eliminate illegal activity once detected. The corporation need not report the activity to the authorities in order to avoid criminal liability, but it must make an effort to stop the activity after it is discovered.

\section{CONCLUSION}

Current theories seeking to explain the decisionmaking processes within organizations indicate that corporations are not always reducible to individuals. Thus, any rule of law that is based on such a reduction is necessarily limited. The rule by which intent is imputed from individuals to corporations suffers from such limitations. It makes prosecution of intent crimes especially difficult in cases in which an opaque corporate structure masks the responsible individuals. Furthermore, the rule makes prosecution impossible where the diffusion of responsibility and the coalescent nature of corporate decisionmaking result in corporate acts that are not consciously intended by any one individual.

The inability to prosecute corporations in these situations is unacceptable. Social scientists argue ${ }^{184}$ that allowing socially harmful beliavior to go unpumished not only encourages such behavior but also has otler damaging sociological consequences, such as the undermining of the public's respect for the law. The current metlod of prosecution for corporate intent crimes creates just this result. From a prosecutor's standpoint, the rule of imputing intent from individuals to the corporation has proven a difficult one. In cases involving large, complex corporations it may be wholly unworkable.

The purpose of this proposed franework is to recoguize corporate intent as a plienomenon distinct from the intent of individual corporate agents, and to shift the focus of the intent inquiry from the individual to the corporation's internal decisionmaking structure. The three prongs attempt to encompass all situations in which this decisionmaking structure can be deemed to have intended to benefit from criminal actions through both explicit and implicit practices.

184. See, e.g., Stoner, supra note 23, at 1294. 


\section{$-$}

